\title{
World War I — A Personal Story
}

Author(s): Martha Bohachevsky-Chomiak

Source: Kyiv-Mohyla Humanities Journal 4 (2017): 139-143

Published by: National University of Kyiv-Mohyla Academy

http://kmhj.ukma.edu.ua/ 


\title{
World War I — A Personal Story
}

\author{
Martha Bohachevsky-Chomiak
}

(2)

For me, the First World War brings visions of the home I had never known. A strange statement? Let me explain, since of course I did not live during that war. Growing up I heard much about it. My childhood coincided with the entire Second World War, experiences that overwhelmingly make accounts of the First World War bearable. We, children during World War II, did not know any other childhood. Not expecting anything, we were satisfied with little. Our worldview was still that of the World War I generation with our belief in the normality of a life of decent people who share basic ideas about what constitutes good and who know where true values reside. My generation of Ukrainian immigrants who came of age in America in the 1950s and 196os still publicly marked November 1918 and 1919 - liberation and unification of the Ukrainian People's Republic - as a heroic attempt. In our stories, we mused how Ukraine would eventually gain its independence, as other Eastern European states had done after WWI. Our pseudo-European Displaced Persons camp experiences gave us a precarious affinity to things European. My decadeolder brother dismissed my choice of a history major with a breezy: "Martha has to figure out how we got here." He went on to study mathematics to explore the cosmos, while I scurried into the ever more labyrinthine presentations of the past.

As wars go, the First World War, known as the Great War, was not long — formally a mere four years. Its impact especially on Western Europe, however, cannot be overstated. The memory of that war is still very much alive in resurging contemporary movements. WWI proved the weakness of Empires, the limitations of education, and especially the fragility of even noncombatant lives, but it also held out the possibility of an alternative way.

The First World War brought a largely unwilling United States into the European bloodshed and politics. The United States entered the war to put an end to all future wars. The horror of the war was underscored toward its end by the outbreak of a deadly influenza that killed more people than the war. President Woodrow Wilson tried to restructure old royal secret diplomacy into "open covenants openly arrived at" by the new democratic diplomats. The Versailles Peace and the establishment of the League of Nations validated the anti-imperial stance worldwide and offered a real promise of future avoidance of wars. The hope was that the people who ended the war that the imperial states began would assure a peaceful future. Even now as the memory of the War fades, its legacy of a promised peace that would end in an opportunity to build a better world plods along in the United Nations. We hope in the attractive power of peace.

For Eastern Europeans the legitimacy of a nation state was the golden nugget that the fires of WWI illuminated. Parts of the world, but especially Eastern Europe went through an actual decolonization and state formation process, with all the attendant characteristics - international involvement, arbitrary delineation of borders, even the beginnings of forcible population shifts. But old back-room closed door diplomacy proved stronger than the new international system, and Ukraine, lacking a real international voice, lost on all counts. Ironically, Ukraine's only 
international success was to push for the establishment of a Union of Soviet Socialist Republics, rather than agree to be united with Russia as a mere colonial appendage. In conjunction with Belarus, Russia agreed to the establishment of a Union of Socialist Soviet Republics, which eventually included 15 national republics. The three constituent republics - Russia, Ukraine, and Belarus - formally had the right to secede from the Union. As the Wilsonian principles of peace and open diplomacy, so the right of secession proved to be difficult to implement.

For many Ukrainians WWI offered hopes of liberation and national assertion. But the Great Peace of Versailles did not reach Eastern Europe; the War morphed seamlessly into the quest for nationhood. At the beginning of the First World War Ukrainians fought on both sides of the conflict, having for centuries been divided among competing states. But as wars and revolutions tapered off, more Ukrainians became aware of being Ukrainian. The people wanted their state. Some joined hands in a struggle for Ukrainian independence, others fought for communism in Ukraine.

Civilian losses and the expansion of information technology that provided visual exposure of the carnage made the elites fear a resurgence of hostilities. Most Western diplomats looked into the reasons for the War to make certain that nothing would be repeated that could — God forbid - lead to the outbreak of another war. All possible reasons for the outbreak of WWI were charted, analyzed, at times even numbered. More and more people believed in peace at any cost. Diplomats were so careful not to repeat earlier missteps, they so dreaded the replay of war that they failed to see how the circumstances changed even as a proxy — now known as hybrid — war erupted on the European rim in Spain.

During the Soviet period, the whole Ukrainian national liberation movement of 1917-1922 was swept under the Marxist rug. What is more, a full-scale unending propaganda war was launched against both the participants and the historic events until the very end of the USSR, and continues in some form today. Participants in the various phases of the Liberation Struggle felt the ire of the Soviets, who claimed both the mantle of the people and knowledge about the future.

The dislocations of WWI and its aftermath reinforced the idea of a large variegated Ukrainian nation. For Ukrainians, the term for nation and people - narod - is interchangeable. And although that causes confusion, it reflects how most Ukrainian citizens today see themselves and their state as one people of Ukraine, regardless of ethnic or confessional choice. That is how the founders of the Ukrainian People's/National Republic envisaged it in 1917. For the communists, as well the imperialists, the Ukrainian state builders of the past remain present-day traitors to the Russian empire. The struggle for Ukrainian liberation in 1917 was not studied in Soviet schools so there is relatively little commemoration of its various phases today.

In Western Ukraine, and among the wave of refugees and émigrés from the Ukrainian territories, the failure of the Liberation Struggle was visceral. It was personal. The interwar occupying powers - Poland, Hungary, Romania - in contrast to the system in the USSR, adhered to a semblance of law and could not stamp out the recent past. Families had lost loved ones in the war, the maimed were visible, discrimination was palpable, the past lived in the present. There were stories of the War and moving songs and commemorations.

In the poverty of small overcrowded Halychyna, the realization of belonging to a great Ukrainian nation, albeit not yet independent and perhaps not yet aware of its potential, did much 
to boost morale. The Liberation Struggle lived, especially among the Western Ukrainian youth that lacked access to schools and jobs. Their interwar generation cherished a militant morale, to the extent of violating behavioral gentility to steel themselves for the inevitable struggle, be it even bloody.

For the Ukrainians, the failure of the struggle for liberation, the failure to consolidate and preserve a state, meant that the First World War and the prelude to that struggle had to be studied to ensure that the next time around the result would be different, favorable to Ukraine. The generation preceding ours tried to document their activities, tried to write the story so that those who read it would understand their failures and do better the next time an opportunity arose. It was difficult work - exiles, without financial backing or access to archival materials, lacking institutional support and external validation, they nevertheless did what they could and produced volumes of important archival documentary materials. All the émigré scholarly institutions - the Shevchenko Scientific Society, the Ukrainian Free Academy of Sciences, the Eastern European Research Institute - sought to promote research on Ukraine and preserve Ukrainian historical records. They all functioned on volunteer donations and a largely volunteer staff. A tiny amount of that work was done in the very modest row house in Philadelphia's working class district that was my family's first individual home in the United States.

When we arrived in the US at the end of the 1940s the hard work of establishing a Ukrainian cultural presence in America had been done by the Ukrainian immigrant pioneers and their children at a time when Americans did not look kindly at minorities in their midst. Nevertheless, Ukrainians built their churches, schools and community centers and eventually made multiculturalism a hallmark of Americanism, not its nemesis. We joined the process.

My father had taken part in WWI as a Habsburg-Austrian conscript and then a volunteer in the Ukrainian Halychyna Army. That War had also claimed the lives of two of his brothers. He would have fought in WWII, despite the protests of my mother and her wailing infant (me), but was rejected for being near-sighted and tubercular. He was turning $5^{\circ}$. After WWII, we made it to the United States. My father, who was proud to have been a lawyer with a doctorate, ended up washing hospital floors and transporting cadavers.

I suspect that to preserve his sense of self when we arrived in the US, he talked much then about the First World War. Or perhaps he went back to the First World War to drown the horror of the WWII experiences and the immediacy of Soviet control of his native land, the death of his father-in-law en route to Siberia, and the unhappy fate of his colleagues. So he relived his youth. But instead of limiting the stories to family and friends, I heard first-hand accounts about the royal Habsburg prince who fought in the ranks of the Ukrainian army in 1918-1919 and was arrested and killed by the Soviets after 1945. Petliura, Hrushevskyi, the Hetman and his son, and of course the women who fought in the Ukrainian detachments were part of daily conversation at dinner. They all could have walked through the door and be recognized. Their stories made the Berlin Airlift pale. Their history became as much a part of my growing up as comics, seven-cent ice-cream cones, and smuggled movie magazines.

At home, when we prepared for the religious holidays that were as much anchored in the kitchen as in the church, we recreated the open house atmosphere of an ideal parsonage in Halychyna. An Eden to have been achieved by the success of the quest for Independence. The 
record player scratched renditions of the WWI songs that played on the stereo set in the living room. Stories of the recent young veterans returning from the Korean conflict could not hold a candle to the by now well-rehearsed accounts of WWI prowess.

My father's colleagues contributed their experiences. For the most part they stressed the positive, especially the funny. Even about the Polish prisoner of war camps, even about Siberia, and all the deaths from infections as much as about their own foibles. For all the foibles, the underpinning of each tale was somber. These were matters not to be taken lightly. I listened to grown men reshuffle historical events, the wonderful if-only-version of history that served as conversation and entertainment as much as history. Compared to the atrocities we witnessed and experienced in WWII, WWI came to be seen as a prelude to the Struggle for Liberation (vyzvolni zmahannia). Some in the generation of my father felt they had almost touched that mythical independent Big (Velyka) Ukraine, but it slipped from their frozen fingers. Now they had to make certain that the younger generation, although no longer in Ukraine, would not forget what was their history.

Some men, and unfortunately fewer women, encouraged each other to put their thoughts on paper, which by the way, many still considered to be a costly deficit item. My father, for instance still used the reverse side of incoming letters, as the ones the University of Pennsylvania sent me when I was applying to study there in 1956. (Now we save paper to recycle it; they saved paper to reuse it immediately.) They saved money from their small salaries to support scholarly causes, such as the Ukrainian institute at Harvard. They joined as affiliate members the Shevchenko Scientific Society, which prided itself in being Ukraine's first academy of sciences, knowing that their own scholarly careers were largely over.

For the older generation, it was not the War that mattered, it was the reason for which they felt they personally had to have been in the War. They saw the war, as inevitable as it was, not in terms of conflict but for the opportunity that could be wrested from it. No one wanted to go to war, but the potential opportunities of the war's outcome remained an attractive possibility. Ukrainians saw WWI as an opportunity to finish what Hetman Mazepa had wanted to reestablish — an independent Ukraine.

So as I rolled up my dungarees (as jeans were known, but not yet considered proper attire for the living room) and pedaled my bike up and down Philadelphia's streets, I found myself thinking of the different ways we view wars, empires, our own lives. As I showed our out-oftown visitors historic Philadelphia, we talked about the long Ukrainian road toward statehood. We were trying to visualize the Ukraine that was off limits to us physically. With my teen-age friends we argued politics and chose speakers for our informal gatherings, for which the formal immigrant institutions gave us free meeting space. We began to engage in public conversations and debate. We became critical of our elders.

Today we view war as a failure of diplomacy, a clash of intolerances, a grave error of both warring sides. We in the USA were blessed with a hundred years of peace, although at times the violence gripping us had all the signs of war. But it was not war. We Americans abhor war. Even when, in the 1950s-1960s as the Western Empires that survived the wars disintegrated, we abhorred the bloodshed of the colonial wars of Liberation.

During his whole life, my father, the veteran of WWI and a survivor of WWII work camps, would not let anything undermine his firm belief in Ukraine's eventual independence 
as a law-abiding state. We argued politics with him at home, and he publicized his views in Ukrainian language publications in America. He was 95 when he died, six years shy of Ukraine's independence. Most of us were lucky to have lived to experience the age-long dream of a Free Ukraine become a normal state. A few of us even got to work in Ukraine for a few years.

A hundred years after the end of WWI, the war that was to end all wars (as WWI used to be described), Ukraine is again facing an intolerant neighbor, a holdover from imperial pre-WWI times. Eastern Europeans marking the centenary of the hostilities of WWI view the present with fear, as Russia again pushes southward. A century after the end of the "war to end all wars" soldiers of the Ukrainian army stand and die defending their state. Wars prove the need for defense. And the United States is again critical of Wilson's ideas of international cooperation.

Martha Bohachevsky-Chomiak, a Phi Beta Kappa graduate of the University of Pennsylvania, holds an MA, PhD and Russian Institute Certificate from Columbia University, and has been the recipient of many grants and awards. She has published a number of books on key issues in Russian and Ukrainian history, and is best known for her trailblazing study of women in Ukraine, Feminists Despite Themselves. She has taught at Manhattanville College and Johns Hopkins, George Washington, Catholic and Harvard universities, as well as at Kyiv National University, the National University of Kyiv-Mohyla Academy, and the Ukrainian Catholic University, from which she holds an honorary doctorate. In retirement, she is completing a book on the consolidation of the Ukrainian Catholic Church in the United States. She was married for more than 5 o years to the late Ross L. Chomiak, a journalist, and has two daughters and four grandchildren. 